\title{
Characterization of Glycoside and Polysaccharide Hydrolases Secreted by the Rumen Anaerobic Fungi Neocallimastix frontalis, Sphaeromonas communis and Piromonas communis
}

\author{
By MICHEL HÉBRAUD* AND MICHEL FÈVRE \\ Laboratoire de Différenciation Fongique, UA CNRS 1127, Université de Lyon 1, \\ 43 Bd du 11 Novembre 1918, 69622 Villeurbanne Cedex, France
}

(Received 18 August 1987; revised 20 December 1987)

\begin{abstract}
The rumen anaerobic fungi Neocallimastix frontalis, Sphaeromonas communis and Piromonas communis were grown in the presence of cellulosic substrate (sisal fibres) and the properties of the glycosidases and polysaccharide-degrading enzymes produced by the organisms were studied. $\beta$-D-Glucosidase (EC 3.2.1.21), $\beta$-D-fucosidase (EC 3.2.1.38), $\beta$-D-galactosidase (EC 3.2.1.23), $\beta$-1,3-glucanase (EC 3.2.1.6), $\beta$-1,4-glucanase (EC 3.2.1.4) and $\beta$-xylanase (EC 3.2.1 .8) had pH optima of 6.0 and temperature optima under the conditions of assay of 50 $55^{\circ} \mathrm{C}$, whereas for $\beta$-xylosidase (EC 3.2 .1 .37 ) the optima were 6.5 and $39^{\circ} \mathrm{C}$ respectively. The apparent $K_{\mathrm{m}}$ values of individual enzymes secreted by the three fungi were similar. The results show that $S$. communis, $P$. communis and $N$. frontalis produce the same range of enzymes, with similar properties, able to degrade cellulose and hemicellulose.
\end{abstract}

\section{INTRODUCTION}

Anaerobic aquatic phycomycetes occur in the rumen of cattle, sheep and goats (Bauchop, 1981; Orpin, 1984; Orpin \& Munn, 1986). The species examined in the sheep rumen are Neocallimastix frontalis, Neocallimastix patriciarum, Piromonas communis and Sphaeromonas communis. Speciation has been based primarily on zoospore morphology and size, number and length of flagella. These phycomycetes are seen consistently in rumen liquid, and measurement of chitin, a polysaccharide constituent of the cell wall of these fungi, indicates that the fungal biomass may represent as much as $8 \%$ of the total microbial biomass (Orpin, 1981), suggesting a significant role in rumen function.

Zoospores of the fungi colonize and invade fibrous plant materials, and are involved in cell wall polysaccharide degradation and fibre digestion. Anaerobic fungi have been cultured on a wide range of polysaccharides, including cellulose, starch, xylan and other hemicelluloses, indicating that they produce the range of enzymes necessary to degrade these polymers to simple sugars (Orpin \& Letcher, 1979; Lowe et al., 1987a; Williams \& Orpin, 1987a). Different isolates of Neocallimastix produce extracellular cellulase, carboxymethylcellulase and xylanase (Mountfort \& Asher, 1985; Pearce \& Bauchop, 1985; Lowe et al., 1987b; Wood et al., 1986). However, investigations have been mainly focused on Neocallimastix frontalis. The properties of other fungi have not been studied apart from recent reports (Williams \& Orpin, 1987a,b) showing that $N$. patriciarum, $P$. communis and an unidentified isolate $(F)$ produce a wide range of glycosidases. In this paper, we have characterized the glycosidases and polysaccharidases produced by three anaerobic fungi, $N$. frontalis, $S$. communis and $P$. communis, in order to determine the contribution of these fungi to rumen function.

\section{METHODS}

Strains and culture conditions. $N$. frontalis, $S$. communis and $P$. communis were isolated from different sheep and identified at the Laboratoire de Microbiologie, CRZV-INRA, Theix, France. Anaerobic techniques for the preparation of culture media were based on those described by Hungate (1969) and Fonty et al. (1987). The fungi 
were isolated by dilution of sheep rumen fluid in anaerobic medium containing $15 \%(\mathrm{v} / \mathrm{v})$ clarified rumen fluid in roll tubes (Joblin, 1981). Colonies were transferred to liquid medium containing $30 \mathrm{mg}$ each of chloramphenicol, ampicillin and streptomycin $\mathrm{ml}^{-1}$. Then they were reinoculated into roll tubes and reisolated to obtain pure cultures. Stock cultures were maintained on sisal medium and $0.5 \mathrm{ml}$ of the culture was transferred to fresh medium every 3 or $4 \mathrm{~d}$. The fungi were grown axenically at $39^{\circ} \mathrm{C}$ in culture tubes containing $5 \mathrm{ml}$ medium containing rumen fluid (Orpin, 1975). Sisal fibres and $0.25 \%$ glucose for $S$. communis and $P$. communis or $0.25 \%$ $(\mathrm{w} / \mathrm{v})$ cellobiose for $N$. frontalis were included in the media. The gas phase was $100 \% \mathrm{CO}_{2}$. Experimental media were inoculated with $0.1 \mathrm{ml}$ zoospore suspension from a $3 \mathrm{~d}$ old culture. Cultures were kept in a vertical position without shaking for $6 \mathrm{~d}$.

Enzyme preparation. For each fungus, several culture tubes were pooled and centrifuged at $3000 \mathrm{~g}$ for $5 \mathrm{~min}$ to pellet mycelia. Pellets were rinsed by centrifugation with $10 \mathrm{ml}$ sodium citrate/phosphate buffer $(100 \mathrm{~mm}, \mathrm{pH} 5 \cdot 2)$. Supernatants were used as the extracellular fraction. Mycelia resuspended in $3 \mathrm{ml}$ buffer were homogenized in a Virtis homogenizer for three periods of $30 \mathrm{~s}$ at high speed and $4{ }^{\circ} \mathrm{C}$, then centrifuged at $1000 \mathrm{~g}$ for $10 \mathrm{~min}$ to sediment the cell wall fraction. Supernatants were centrifuged at $48000 \mathrm{~g}$ for $30 \mathrm{~min}$ to obtain the intracellular soluble fraction (supernatant) and the membrane fraction (pellet). Cell wall and membrane fractions were resuspended in $3 \mathrm{ml}$ buffer (Fèvre, 1977).

Enzyme assays. $\beta$-1,3-Glucanase (1,3- $\beta$-D-glucan glucanohydrolase, EC 3.2.1.6), $\beta$-1,4-glucanase $(1,4-\beta$-Dglucan 4-glucanohydrolase 4-glucanohydrolase, EC 3.2.1.4) and xylanase (1,4- $\beta$-D-xylan xylanohydrolase, EC 3.2.1.8) activities were measured in a final volume of $1 \mathrm{ml}$ containing respectively laminarin (1 mg), carboxymethylcellulose $(3 \mathrm{mg})$ and xylan $(1.5 \mathrm{mg})$ dissolved in citrate/phosphate buffer $(100 \mathrm{mM}, \mathrm{pH} 6.0)$ and $10-$ $50 \mu \mathrm{l}$ of enzyme preparation. After $20 \mathrm{~min}$ incubation at $50^{\circ} \mathrm{C}$, reactions were stopped by the addition of $3 \mathrm{ml}$ dinitrosalicylic acid (DNS) reagent (Miller, 1959) to measure reducing sugars liberated. Tubes were placed in a boiling water-bath for $8 \mathrm{~min}$. Absorbances were read at $528 \mathrm{~nm}$ with glucose or xylose as standards. Enzyme and substrate controls were included in all assays. Enzyme activities are expressed as $\mu \mathrm{mol}$ glucose or xylose equivalent released $\min ^{-1}$ ( $\mathrm{ml}$ enzyme solution $)^{-1}$.

$\beta$-D-Glucosidase $(\beta$-D-glucoside glucohydrolase, EC 3.2.1.21), $\beta$-D-fucosidase $(\beta$-D-fucoside fucohydrolase, EC 3.2.1 .38), $\beta$-D-xylosidase ( $\beta$-D-xyloside xylohydrolase, EC 3 2.1.37) and $\beta$-D-galactosidase ( $\beta$-D-galactoside galactohydrolase, EC 3.2.1.23) were determined by measuring the $p$-nitrophenol released from $p$-nitrophenyl $\beta$ D-glucoside, $p$-nitrophenyl $\beta$-D-fucoside, $p$-nitrophenyl $\beta$-D-xyloside and $p$-nitrophenyl $\beta$-D-galactoside respectively. The reaction mixtures contained $10-50 \mu \mathrm{l}$ of enzyme solution in $1 \mathrm{ml}$ substrate solution $(1 \mathrm{mg}$ in citrate/phosphate buffer, $100 \mathrm{~mm}, \mathrm{pH} \mathrm{6.0)}$ ). After $20 \mathrm{~min}$ at $50^{\circ} \mathrm{C}$ or $39^{\circ} \mathrm{C}$, reactions were terminated by the addition of $2 \mathrm{ml} 1 \mathrm{M}-\mathrm{Na}_{2} \mathrm{CO}_{3}$. The $p$-nitrophenol liberated was measured spectrophotometrically at $400 \mathrm{~nm}$. One unit of enzyme activity is defined as that required to produce $1 \mathrm{nmol} p$-nitrophenol $\mathrm{min}^{-1}$ (ml of enzyme solution $)^{-1}$. All enzyme reactions were linear over the period of assay.

Other glycosidase activities were screened using LRA ZYM OSIDASES (API, France). Assays were conducted with $65 \mu \mathrm{l}$ culture medium at $40^{\circ} \mathrm{C}$ for $4 \mathrm{~h}$. Glycosidase activity was detected by the addition of a drop of $0 \cdot 1 \mathrm{M}-\mathrm{NaOH}$.

Determination of enzyme properties. The effect of substrate concentration on each enzyme activity was tested in the range of $0 \cdot 25-4 \mathrm{mg} \mathrm{ml}^{-1} . K_{\mathrm{m}}$ values were determined using the Lineweaver-Burk plot. The optimum $\mathrm{pH}$ and temperature under the conditions of assay for each enzyme activity was determined by measuring enzyme activity in citrate/phosphate buffer $(100 \mathrm{mM})$ at $\mathrm{pH}$ values ranging from 3.0 to 8.0 and temperatures from 20 to $70{ }^{\circ} \mathrm{C}$. The effect of $\mathrm{pH}$ on enzyme stability was determined by incubating crude enzyme adjusted to $\mathrm{pH} 3.0$ to 8.0 for $1 \mathrm{~h}$ at $20^{\circ} \mathrm{C}$. Thermal stability was determined by incubating enzyme solutions without their substrates in citrate/phosphate buffer, $100 \mathrm{~mm}, \mathrm{pH} \mathrm{6.0,} \mathrm{for} 4 \mathrm{~h}$ at different temperatures. Residual activities were measured using standard assay conditions.

\section{RESULTS}

\section{Enzyme production by rumen anaerobic fungi grown on sisal fibres}

When they were grown in the presence of sisal fibres, $N$. frontalis, $S$. communis and $P$. communis secreted into the medium several endo-enzymes $(\beta$-1,3-glucanase, $\beta$-1,4-glucanase, xylanase) and exo-enzymes ( $\beta$-glucosidase, $\beta$-fucosidase, $\beta$-xylosidase, $\beta$-galactosidase). As maximal activities and maximal growth of the cultures occurred at the same time, analyses were done on $6 \mathrm{~d}$ old cultures (Table 1 ). $N$. frontalis had the highest $\beta$-1,4-glucanase activity while the two other fungi showed greater exo-enzyme activities. Among the exo-enzymes, $\beta$-galactosidase had a very low activity, 16 to 30 times lower than that of $\beta$-fucosidase.

Attempts to detect other glycosidase activities like mannanase, $\alpha$-glucosidase, $\alpha$-galactosidase, $N$-acetyl- $\alpha$-or $\beta$-D-glucosaminidase, $\alpha$-xylosidase, $\alpha$-or $\beta$-maltosidase, $\alpha$-or $\beta$-mannosidase, 


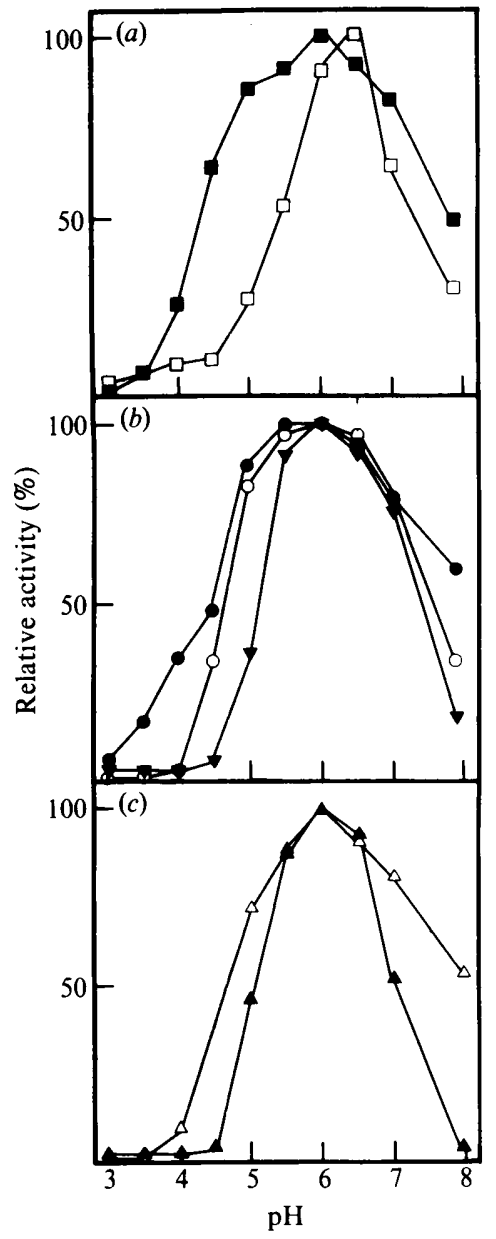

Fig. 1

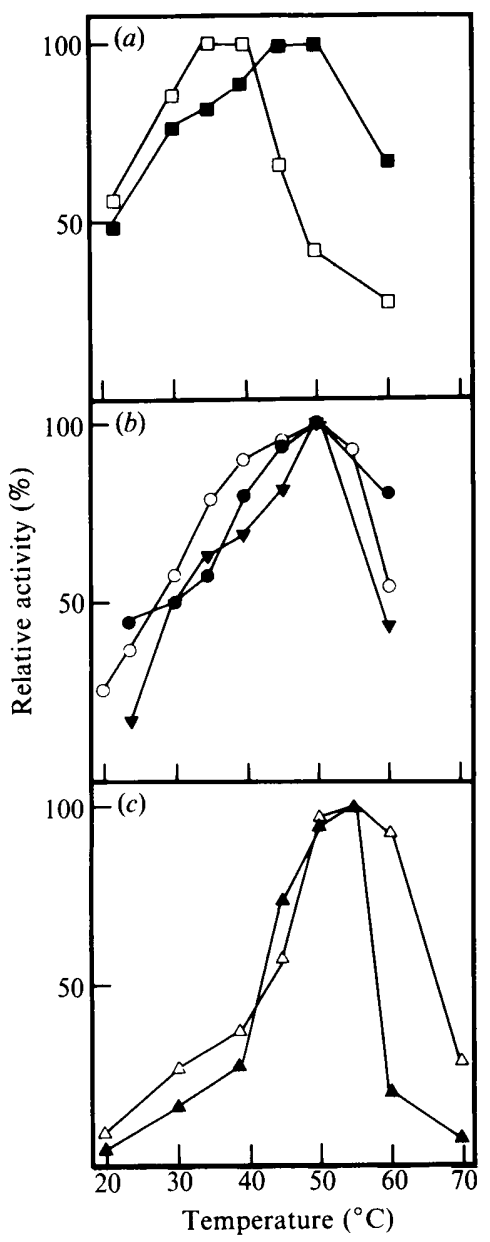

Fig. 2

Fig. 1. Effect of $\mathrm{pH}$ on the activity of extracellular enzymes of $N$. frontalis. (a) $\square$, Xylanase; $\square$, $\beta$-xylosidase. (b) $\mathcal{O}, \beta$-1,4-Glucanase; $\bigcirc, \beta$-glucosidase; $\nabla, \beta$-galactosidase. $(c) \Delta, \beta$-Fucosidase; $\triangle$, $\beta$-1,3-glucanase.

Fig. 2. Effect of temperature on the activity of extracellular enzymes of $N$. frontalis. (a) $\square$, Xylanase; $\square, \beta$-xylosidase. (b) $\bigcirc, \beta$-1,4-Glucanase; $\bigcirc, \beta$-glucosidase; $\boldsymbol{\nabla}, \beta$-galactosidase. $(c) \Lambda$, $\beta$-Fucosidase; $\triangle, \beta$-1,3-glucanase.

Table 1. Glycosidase and polysaccharidase activities in the culture media of rumen anaerobic fungi

Extracellular enzymic activities were measured in $6 \mathrm{~d}$ old cultures and are expressed as nmol $p$ nitrophenol released $\min ^{-1}(\mathrm{ml} \text { culture })^{-1}(a)$ or as $\mu$ mol glucose $(b)$ or xylose $(c)$ equivalents produced $\mathrm{min}^{-1}(\mathrm{ml} \text { culture })^{-1}$. The results are the means \pm SD of five experiments for $N$. frontalis and of three experiments for $S$. communis and $P$. communis.

$$
\text { Activity }
$$

$\beta$-Glucosidase ${ }^{a}$

$\beta$-Fucosidase ${ }^{a}$

$\beta$-Xylosidase ${ }^{a}$

$\beta$-Galactosidase ${ }^{a}$

$\beta$-1,3-Glucanase ${ }^{b}$

$\beta$-1,4-Glucanase ${ }^{b}$

Xylanase $^{c}$
$N$. frontalis

$$
\begin{gathered}
15 \pm 10 \\
48 \pm 12 \\
16 \pm 6 \\
3 \pm 0 \cdot 8 \\
0 \cdot 31 \pm 0.03 \\
0 \cdot 44 \pm 0.08 \\
0 \cdot 36 \pm 0.05
\end{gathered}
$$

S. communis

$$
46 \pm 12
$$

$66 \pm 10$

$27 \pm 5$

$3 \cdot 7 \pm 0 \cdot 7$

$0.24 \pm 0.03$

$0.31+0.04$

$0.43 \pm 0.06$
P. communis

$$
\begin{gathered}
20 \pm 8 \\
55 \pm 7 \\
28 \pm 3 \\
2 \pm 0.5 \\
0.26 \pm 0.04 \\
0.27 \pm 0.05 \\
0.37 \pm 0.04
\end{gathered}
$$




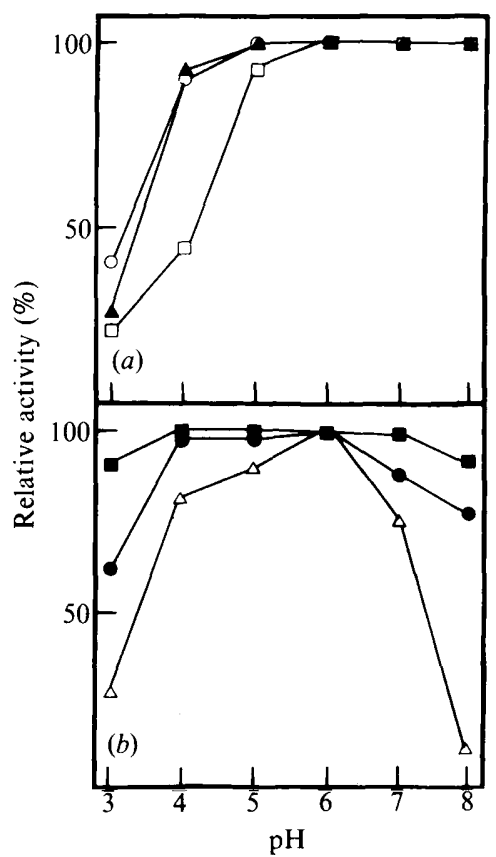

Fig. 3

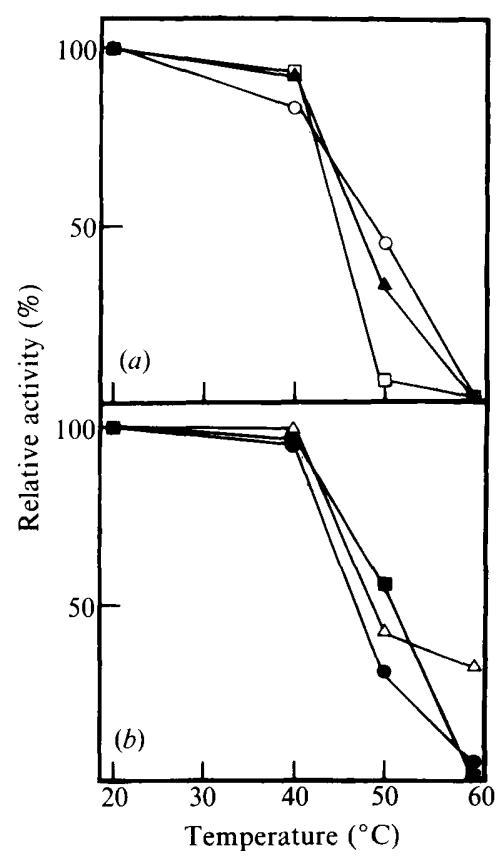

Fig. 4

Fig. 3. pH stability of extracellular enzymes of $N$. frontalis. (a) $\square, \beta$-Xylosidase; $\boldsymbol{\Delta}, \beta$-fucosidase; $\bigcirc, \beta$ glucosidase. (b) $\square$, Xylanase; $\triangle, \beta$-1,3-glucanase; $\boldsymbol{O}, \beta$-1,4-glucanase. Crude enzymes adjusted to $\mathrm{pH}$ $3 \cdot 0-8 \cdot 0$ were incubated for $1 \mathrm{~h}$ at $20^{\circ} \mathrm{C}$ before assaying residual enzyme activity.

Fig. 4. Temperature stability of extracellular enzymes of $N$. frontalis. (a) $\square, \beta$-Xylosidase; $\boldsymbol{\Delta}, \beta$ fucosidase; $O, \beta$-glucosidase. $(b) \square$, Xylanase; $\triangle, \beta$-1,3-glucanase; $\boldsymbol{O}, \beta$-1,4-glucanase. Enzyme preparations were incubated for $4 \mathrm{~h}$ at various temperatures in citrate/phosphate buffer (100 mM, pH 6.0) without substrates, before estimating residual activities.

$\alpha$ - or $\beta$-L-fucosidase were not convincing. The amounts of $p$-nitrophenol released from $p$ nitrophenyl substrates were so low that we could not exclude the action of non-specific hydrolases.

$\beta$-1,4-Glucanase and xylanase were found mainly in the extracellular fraction, which contained 95 and $99 \%$, respectively, of the total activities. Most (75 and $90 \%$ ) of the total $\beta$ xylosidase and $\beta$-glucosidase was also recovered in the medium. Their intracellular activities were also determined following differential centrifugation of cell-free extracts obtained with a razor blade homogenizer which allowed an efficient breakage of mycelia (Fèvre, 1977). These enzymes were associated with the cell wall fraction ( $10 \%$ of the total activity). $\beta$-Xylosidase was also found in the internal membranes and in the intracellular soluble fraction corresponding to about 10 and $5 \%$, respectively, of the total activity. Only traces of $\beta$-glucosidase were detected in these fractions.

As the culture media contained most of the enzyme activities they were used as the enzyme sources for the following experiments.

\section{Properties of the enzymes secreted by $N$. frontalis}

Physicochemical characteristics of the enzymes produced by $N$. frontalis were determined. $\beta$ $\mathrm{Xylosidase}$ and $\beta$-fucosidase were active in a very narrow range of $\mathrm{pH}$ values and temperatures: maximal activities were obtained respectively at $\mathrm{pH} 6.5$ and $39^{\circ} \mathrm{C}$ and at $\mathrm{pH} 6.0$ and $55^{\circ} \mathrm{C}$ (Figs 1 and 2). Slight deviations from these optimal conditions resulted in a sharp decrease of the enzyme activities. $\beta$-Glucosidase, $\beta$-1,4-glucanase, $\beta$-xylosidase and $\beta$-1,3-glucanase exhibited 
Table 2. Comparison of the properties of the hydrolases secreted by $N$. frontalis $(N . f$.$) ,$

$S$. communis $(S . c$.) and $P$. communis $(P . c$.)

\begin{tabular}{|c|c|c|c|c|c|c|c|c|c|}
\hline \multirow[b]{2}{*}{ Activity } & \multicolumn{3}{|c|}{$\begin{array}{l}\text { Optimum } \\
\text { temperature* } \\
\left({ }^{\circ} \mathrm{C}\right)\end{array}$} & \multicolumn{3}{|c|}{ Optimum $\mathrm{pH}^{*}$} & \multicolumn{3}{|c|}{$\begin{array}{c}K_{\mathrm{m}}^{*} \\
\left(\mathrm{mg} \text { substrate } \mathrm{ml}^{-1} \text { ) }\right.\end{array}$} \\
\hline & N. $f$. & S. $c$. & P. c. & $N . f$ & S. $c$. & P. c. & N. $f$. & S. $c$. & $P . c$. \\
\hline$\beta$-Glucosidase & 50 & 50 & 50 & $6 \cdot 0$ & $6 \cdot 0$ & $6 \cdot 0$ & 0.55 & 0.51 & 0.52 \\
\hline$\beta$-Fucosidase & 55 & 55 & 55 & $6 \cdot 0-6 \cdot 5 \dagger$ & $6.0-6.5 \dagger$ & $6.0-6.5 \dagger$ & $0 \cdot 39$ & $0 \cdot 37$ & $0 \cdot 30$ \\
\hline$\beta$-Xylosidase & 35 & 39 & 39 & 6.5 & $6 \cdot 5$ & $6.0-6.5 \dagger$ & $0 \cdot 34$ & $0 \cdot 36$ & 0.40 \\
\hline$\beta$-Galactosidase & 50 & 50 & 50 & $6 \cdot 0$ & $6 \cdot 0$ & 6.0 & 1.89 & $1 \cdot 20$ & $1 \cdot 24$ \\
\hline$\beta-1,3-$ Glucanase & 55 & 55 & 55 & $6 \cdot 0$ & $6 \cdot 0$ & $6 \cdot 0$ & 0.97 & 0.85 & 0.77 \\
\hline$\beta-1,4-$ Glucanase & 45 & 50 & 50 & $5 \cdot 5$ & $6 \cdot 0$ & 6.0 & $2 \cdot 79$ & $2 \cdot 89$ & $2 \cdot 43$ \\
\hline Xylanase & 50 & 50 & 50 & $6 \cdot 0$ & $6 \cdot 0$ & $5 \cdot 5$ & $1 \cdot 13$ & 0.98 & 1.00 \\
\hline
\end{tabular}

optimal activity between pH 5.5 and 6.5 and at $50{ }^{\circ} \mathrm{C}$. Their activities were only gradually reduced by lowering the temperature or the $\mathrm{pH}$.

The effects of pH (Fig. 3) or temperature (Fig. 4) on enzyme stability showed that most of the enzymes exhibited the same properties: they were stable after $4 \mathrm{~h}$ at $40^{\circ} \mathrm{C}$ and for $1 \mathrm{~h}$ at $\mathrm{pH}$ values between 4 and 8 . However, $\beta$-xylosidase was less stable, being inactivated during incubation at $\mathrm{pH} 4$ or at $50^{\circ} \mathrm{C}$.

\section{Comparison of the properties of the enzymes secreted by different fungi}

The enzymes produced by $P$. communis and $S$. communis were mainly extracellular as more than $80 \%$ of the total activity of each glycosidase was recovered in the culture medium. The properties of the enzymes secreted by these two fungi were determined (data not shown in detail) and compared to those of $N$. frontalis (Table 2). The general properties of each type of enzyme produced by the three fungi were nearly identical. The optimal $\mathrm{pH}$ was 6.0 for each enzyme activity except $\beta$-xylosidase (pH 6.5). Optimum temperatures under the conditions of assay were at 50 or $55^{\circ} \mathrm{C}$ except for $\beta$-xylosidase which was most active at $39^{\circ} \mathrm{C}$. The apparent $K_{\mathrm{m}}$ for each type of enzyme was similar in different species.

\section{DISCUSSION}

A large population of anaerobic fungi is associated with plant material in the rumen of animals receiving fibrous diets. The different strains used in this study were isolated from the sheep rumen and were identified as $N$. frontalis, $P$. communis and $S$. communis according to the size of their zoospores, the number and size of flagella, and the size and shape of their sporangium following the descriptions of Orpin $(1975,1976,1977)$. In order to evaluate the role of these fungi in fibre digestion, the nature and the properties of the glycosidases synthesized by these three species were determined. When cultured in the presence of sisal, $N$. frontalis produced $\beta$-1,3-glucanase and $\beta$-fucosidase in addition to $\beta$-1,4-glucanase, xylanase, $\beta$ xylosidase, $\beta$-glucosidase and $\beta$-galactosidase as previously reported (Pearce \& Bauchop, 1985; Mountfort \& Asher, 1985; Lowe et al., 1987b; Williams \& Orpin, 1987a,b). Most of the total activity of these enzymes was secreted and recovered in culture medium. Internal membranes, cell walls and cytosol exhibited little activity in $6 \mathrm{~d}$ old cultures. These results are in agreement with those of Pearce \& Bauchop (1985) using 6-7 d old cultures of another strain of $N$. frontalis. As most studies have focused on the physiology of Neocallimastix species, it was interesting to determine and to compare the hydrolytic activities produced by two other species, $P$. communis and $S$. communis. They exhibited the same range and nature of exo- and endo-acting enzymes produced by $N$. frontalis. They were mainly secreted and their activities were of the same magnitude when the fungi were grown in the presence of sisal. The enzymic properties were similar from one enzyme to another and from one species to another. Thus, these properties 
cannot be used for the identification of new isolates. The enzymes exhibited the same optimum $\mathrm{pH}\left(\mathrm{pH} \mathrm{6.0)}\right.$ and optimum temperature of $50{ }^{\circ} \mathrm{C}$ except for $\beta$-xylosidases. These values are similar to those reported for xylanase and $\beta$-1,4-glucanase from different isolates of Neocallimastix (Mountfort \& Asher, 1985; Lowe et al., 1987b) but differed from those of enzymes degrading Avicel (Pearce \& Bauchop, 1985) and of a wide range of enzymes produced by Neocallimastix patriciarum and $P$. communis which were assayed at $39^{\circ} \mathrm{C}$ (Williams \& Orpin, $1987 a, b)$. The properties of the enzymes were different to those described for enzymes of aerobic fungi, which are commonly active at more acidic $\mathrm{pH}$ values from $\mathrm{pH} 4 \cdot 0$ to $5 \cdot 0$, and at higher temperatures, from 55 to $70{ }^{\circ} \mathrm{C}$ (Hoebler \& Brillouet, 1984; Kamagata et al., 1986; Macris, 1984; Shoemaker \& Brown, 1978; Sadana et al., 1983). $\beta$-Xylosidases, which were more active at $39^{\circ} \mathrm{C}$ and at $\mathrm{pH} 6.5$, were also different to those of aerobic fungi which have optima at pH 4.0-5.0 and 50-75 ${ }^{\circ} \mathrm{C}$ (Lachke et al., 1985; Deshpande et al., 1986; Kitpreechavanich et al., 1986). The enzymes, particularly the $\beta$-xylosidases, were unstable in the absence of substrate after a relatively short incubation $(4 \mathrm{~h})$ at $50{ }^{\circ} \mathrm{C}$. Similar results have been reported for $\beta$-1,4glucanase and xylanase from different Neocallimastix isolates (Mountfort \& Asher, 1985; Lowe et al., 1987b).

The apparent $K_{\mathrm{m}}$ values for each type of enzyme produced by the fungi were similar. Williams $\&$ Orpin $(1987 a, b)$ also observed that the substrate affinities of enzyme preparations from $N$. patriciarum, $P$. communis and isolate $\mathrm{F}$ were similar. Moreover, the $K_{\mathrm{m}}$ values, $1 \mathrm{mg} \mathrm{m}^{-1}$ for xylanase, $0.4 \mathrm{mg} \mathrm{ml}^{-1}$ for $\beta$-fucosidase and $0.35-0.4 \mathrm{mg} \mathrm{ml}^{-1}$ for $\beta$-xylosidase, were similar to those of the enzymes of three different isolates studied by Williams \& Orpin $(1987 a, b)$.

The role of $S$. communis in the rumen was not clear as this species has a very limited rhizoidal system compared to $N$. frontalis and $P$. communis. Our results show that $S$. communis secretes the same wide range of glycoside hydrolases produced by $P$. communis and $N$. frontalis and is able to degrade cellulose, hemicelluloses and non-cellulosic mixed glucans of plant cell walls. Thus, although $S$. communis does not penetrate plant tissues, it probably acts as an active degrader by secreting large amounts of extracellular hydrolases. In order to elucidate the efficiency and the interactions of different polysaccharide depolymerases $(\beta-1,3-$ and $\beta$-1,4-glucanases, xylanase) and glycoside hydrolases ( $\beta$-glucosidase, $\beta$-fucosidase, $\beta$-xylosidase, $\beta$-galactosidase) in the degradation of plant structural polysaccharides, studies involving enzyme induction and the purification of individual enzymes will be necessary.

We would like to thank Drs Ph. Gouet \& G. Fonty (Laboratoire de Microbiologie, INRA, Theix) for providing the different fungal strains. This work is supported by the research programme of the ATP INRA - Optimisation des fermentations dans le rumen.

\section{REFERENCES}

BAUCHOP, T. (1981). The anaerobic fungi in rumen fibre digestion. Agriculture and Environment 6, 339348.

Deshpande, M. V., Lachke, A. H., Mishra, C., KESKAR, S. \& RAO, M. (1986). Mode of action and properties of xylanase and $\beta$-xylosidase from Neurospora crassa. Biotechnology and Bioengineering 28, 1832-1837.

Fèvre, M. (1977). Subcellular localization of glucanase and cellulase in Saprolegnia monoica Pringsheim. Journal of General Microbiology 103, 287-295.

Fonty, G., Gouet, P., Jounan, J.-P. \& Senaud, J. (1987). Establishment of the microflora and anaerobic fungi in the rumen of lambs. Journal of General Microbiology 133, 1835-1843.

Hoebler, C. \& Brillouet, J.-M. (1984). Purification and properties of an endo-(1-4)- $\beta$-D-xylanase from Irpex lacteus. Carbohydrate Research 128, 141-155.

Hungate, R. E. (1969). A roll tube method for the cultivation of strict anaerobes. Methods in Microbiology 3B, 117-132.
JoBLIN, K. N. (1981). Isolation, enumeration and maintenance of rumen anaerobic fungi in roll tubes. Applied and Environmental Microbiology 42, 1119 1122.

Kamagata, Y., Yachi, M., Sasaki, H. \& Takao, S. (1986). Purification and properties of two endocellulases from Penicillium purpurogenum. Agricultural and Biological Chemistry 50, 2989-2995.

Kitpregchavanich, V., Hayashi, M. \& Nagal, S. (1986). Purification and characterization of extracellular $\beta$-xylosidase and $\beta$-glucosidase from $A$ spergillus fumigatus. Agricultural and Biological Chemistry $\mathbf{5 0}$, 1703-1711.

LachKe, A. H., Deshrande, M. V. \& Srinivasan, M. C. (1985). Extracellular $\beta$-D-xylosidase of Sclerotium rolfsii. Enzyme and Microbial Technology 7, 445-448.

Lowe, S. E., Theodorou, M. K., \& Trinci, A. P. J. $(1987 a)$. Growth and fermentation of an anaerobic rumen fungus on various carbon sources and effect of temperature on development. Applied and Environmental Microbiology 53, 1210-1215. 
Lowe, S. E., Theodorou, M. K. \& Trinci, A. P. J. $(1987 b)$. Cellulases and xylanase of an anaerobic fungus grown on wheat straw, wheat straw holocellulose, cellulose and xylan. Applied and Environmental Microbiology 53, 1216-1223.

MACRIS, B. J. (1984). Production and characterization of cellulase and $\beta$-glucosidase from a mutant of Alternaria alternata. Applied and Environmental Microbiology 47, 560-565.

MilleR, G. L. (1959). Use of dinitrosalicylic acid reagent for determination of reducing sugars. Analytical Chemistry 31, 426-428.

MOUNTFORT, D. O. \& AsHER, R. A. (1985). Production and regulation of cellulase by two strains of the rumen anaerobic fungus Neocallimastix frontalis. Applied and Environmental Microbiology 49, 13141322.

ORPIN, C. G. (1975). Studies of the rumen flagellate Neocallimastix frontalis. Journal of General Microbiology 91, 249-262.

ORPIN, C. G. (1976). Studies of the rumen flagellate Sphaeromonas communis. Journal of General Microbiology 94, 270-280.

OrPIN, C. G. (1977). The rumen flagellate Piromonas communis: its life-history and invasion of plant material in the rumen. Journal of General Microbiology 99, 107-117.

ORPIN, C. G. (1981). Fungi in ruminant degradation. In Agricultural Science Seminar: Degradation of Plant Cell Wall Material, pp. 36-47. London: Agricultural Research Council.

OrPIN, C. G. (1984). The role of ciliate protozoa and fungi in the rumen digestion of plant cell walls. Animal Feed Science and Technology 10, 121-143.

OrPIN, C. G. \& LETCHER, A. J. (1979). Utilization of cellulose, starch, xylan, and other hemicelluloses for growth by the rumen phycomycete Neocallimastix frontalis. Current Microbiology 3, 121-124.

ORPIN, C. G. \& MuNN, E. A. (1986). Neocallimastix patriciarum sp. nov., a new member of the Neocallimasticaceae inhabiting the rumen of sheep. Transactions of the British Mycological Society 86, 178-181.

Pearce, P. D. \& Bauchop, T. (1985). Glycosidases of the rumen anaerobic fungus Neocallimastix frontalis grown on cellulosic substrates. Applied and Environmental Microbiology 49, 1265-1269.

Sadana, J. C., Shewale, J. G. \& Patil, R. V. (1983). $\beta$ D-Glucosidases of Sclerotium rolfsii. Substrate specificity and mode of action. Carbohydrate Research 118, 205-214.

Shoemaker, S. P. \& Brown, R. D. (1978). Characterization of endo-1-4- $\beta$-glucanases purified from Trichoderma viride. Biochimica et biophysica acta $\mathbf{5 2 3}$, 147-161.

Williams, A. G. \& OrPIN, C. G. (1987a). Polysaccharide-degrading enzymes formed by three species of anaerobic rumen fungi grown on a range of carbohydrate substrates. Canadian Journal of Microbiology 33, 418-426.

Williams, A. G. \& OrPin, C. G. (1987b). Glycoside hydrolase enzymes present in the zoospore and vegetative growth stages of the rumen fungi Neocallimastix patriciarum, Piromonas communis, and an unidentified isolate, grown on a range of carbohydrates. Canadian Journal of Microbiology 33, 427434.

Wood, T. M., Wilson, C. A., McCrae, S. I. \& Joblin, K. N. (1986). A highly active extracellular cellulase from the anaerobic rumen fungus Neocallimastix frontalis. FEMS Microbiology Letters 34, 37-40. 